\title{
SECURITIES CROWDFUNDING SEBAGAI ALTERNATIF PEMBIAYAAN PADA PELAKU USAHA MIKRO DALAM PERSPEKTIF TEORI HUKUM PEMBANGUNAN
}

\section{SECURITIES CROWDFUNDING AS A FINANCING ALTERNATIVE FOR \\ MICRO BUSINESS IN PERSPECTIVE \\ LEGAL THEORY OF DEVELOPMENT}

\author{
Lukmanul Hakim \\ Fakultas Hukum, Universitas Bandar Lampung \\ Email :Lukman517422@gmail.com \\ Naskah dikirim : 16 Februari 2021 \\ Naskah diterima untuk diterbitkan : 6 Januari 2022 \\ DOI : $10.34010 /$ rnlj.v\%vi\%i.4578
}

\begin{abstract}
The purpose of this study is to determine the optimization of securities crowdfunding as an alternative financing, especially for micro businesses where financing is a major problem for micro business actors today in the digital era. The research method used is qualitative with a descriptive approach. The research results obtained are that through securities crowdfunding financing, it is hoped that it can increase access to finance and can increase business capacity supported by digital access to technology as a means of development, so that it makes it easy for business actors, especially micro start-up businesses to find funding for their business to develop.

Keywords : Securities Crowdfunding, Financing, Micro Business, Development Law.

Abstrak

Tujuan penelitian ini adalah untuk mengetahui optimalisasi securities crowdfunding sebagai alternatif pembiayaan khususnya bagi usaha mikro dimana pembiayaan merupakan masalah utama bagi pelaku usaha mikro saat ini di era digital. Adapun metode penelitian yang dipakai adalah kualitatif dengan jenis pendekatan deskriptif. Hasil penelitian yang diperoleh adalah melalui pembiayaan securities crowdfunding diharapkan dapat meningkatkan akses pembiayaan serta dapat meningkatkan kapasitas usaha dengan ditunjang akses digital teknologi sebagai sarana pembangunan maka memberikan kemudahan bagi para pelaku usaha pada khususnya usaha mikro pemula dalam mencari pendanaan bagi usahanya untuk dapat berkembang.
\end{abstract}

Kata Kunci : Securities Crowdfunding, Pembiayaan, Usaha Mikro, Hukum Pembangunan.

\section{A. PENDAHULUAN}

\section{Latar Belakang}

Era revolusi industri 4.0 memberikan perkembangan pembangunan industri yang sangat pesat terutama perkembangan internet di era ini telah memberikan inovasi khususnya dalam pemenuhan kebutuhan sektor keuangan bagi masyarakat dalam mengakses layanan finansial 
Vol. 4 No. 1 Januari 2022

berbasis digital. ${ }^{1}$ Penggunaan internet dalam kehidupan sehari-hari membuat perilaku manusia berubah yang semula konvensional kini beralih pada digitalisasi.

Berdasarkan data dari asosiasi penyelenggara jasa internet indonesia (APJII) menyebutkan 196 juta populasi warga negara Indonesia atau sekitar 74\% pada kuartal kedua Tahun 2020 masyarakat yang mengakses internet. ${ }^{2}$ Pertumbuhan jumlah pengguna internet sendiri didominasi pulau jawa sebesar 57\% dan Pulau Sumatera sebesar 22\%. Penambahan jumlah pengguna internet ini memberikan dampak yang sangat kuat bagi perekonomian, karena mengingat akses tanpa batas para pengguna untuk dapat membeli barang ataupun jasa pada khususnya.

Perubahan perilaku masyarakat saat ini membuat pelaku usaha mikro harus dapat lebih kreatif dan inovatif dalam menggunakan teknologi untuk dapat meningkatkan usahanya serta mampu berkolaborasi dengan sesama pelaku usaha mikro lainnya untuk dapat meningkatkan kapasitas usahanya. ${ }^{3}$ Disamping itu faktor utama yang seringkali menjadi permasalahan bagi pelaku usaha mikro yang sampai saat ini masih menjadi kendala utama adalah masalah pembiayaan atau akses permodalan yang masih belum tersentuh bahkan beberapa lembaga keuangan bank dan non bank masih belum melirik usaha mikro. ${ }^{4}$

Pengembangan teknologi memberikan dampak positif yang cukup besar bagi kehidupan masyarakat saat ini. Namun juga memiliki dampak negatif juga, karena dengan pemanfaatan teknologi akhirnya mendorong terjadinya era disruptive sehingga perlu adanya penyesuaian bagi masyarakat serta pelaku usaha. ${ }^{5}$

Kontribusi perekonomian saat ini didominasi oleh para pelaku usaha mikro tentu dalam PDB mencapai $70 \%$ dimana pelaku usaha mikro menjadi faktor pendorong sektor ekonomi informal di Indonesia. ${ }^{6}$ Usaha mikro yang memiliki karakteristik usaha informal yang mengalami keterbatasan dalam sektor pembiayaan dapat menggunakan securities crowdfunding sebagai salah satu alternatif pembiayaan dimana securities crowdfunding memiliki perbedaan dengan pembiayaan financial technology seperti peer to peer landing yang tidak mungkin digunakan oleh usaha mikro mengingat mahalnya suku bunga yang diberikan oleh P2P Landing sehingga penggunaan fintech landing tidak dapat dijadikan alternatif pembiayaan bagi usaha mikro karena $\mathrm{P} 2 \mathrm{P}$ memberikan bunga yang relatif mahal dan tinggi daripada lembaga perbankan.

Securities crowdfunding sendiri disempurnakan oleh otoritas jasa keuangan melalu peraturan otoritas jasa keuangan 57/2020 tentang penawaran efek melalui layanan urun dana berbasis teknologi yang diluncurkan pada bulan desember 2020. Peraturan otoritas jasa keuangan ini hadir sebagai alternatif bagi pelaku usaha mikro pemula dalam mencari pendanaan bagi usahanya. Regulasi ini menggantikan peraturan jasa keuangan nomor 37/POJK.04/2018

${ }^{1}$ Ayu Putu Yulia Kusuma Wardani Dan Nyoman Ari Surya Darmawan, Peran financial technology pada UMKM : Peningkatan literasi keuangan berbasis payment gateaway, Jurnal Ilmiah Akuntansi dan Humanika, Vol 10 No 2, Mei- Agustus 2020 Hlm 170

${ }^{2}$ https://teknologi.bisnis.com/read/20201110/ diakses pada tanggal 11 Februari 2021

${ }^{3}$ Eka Travilta Oktaria dan Desi Derina Yusda, Efektivitas Penerapan Tanggung Jawab Sosial Perusahaan Terhadap Pengembangan Usaha mikro, Jurnal Ekombis, Vol 5 No 1 Tahun 2020. Hlm 7

${ }^{4}$ Eka Travilta Oktaria, Pengembangan UMKM Dalam Pembiayaan Berbasis Koperasi Dalam Rangka Peningkatan Ekonomi di Indonesia, Jurnal Ekombis, Vol 3 No 1 Tahun 2018 Hlm 3

${ }^{5}$ Hanik Fitriani, Kontribusi Fintech dalam Meningkatkan Keuangan Inklusif pada Pertanian. ElBarka : Jurnal Of Islamic Economics And Business, Vol 1 No 1 Tahun 2018, Hlm 26.

${ }^{6}$ Sifwatir Rif'ah, Fenomena Cashless Society di Era Milenial Dalam Perspektif Islam, AlMusthofa: Journal of Sharia Economics, Vol 2, No 1 Tahun 2019, Hlm 10 
Vol. 4 No. 1 Januari 2022

tentang layanan urun dana melalui penawaran saham berbasis teknologi informasi. Peraturan ini juga diperluas mencakup efek bersifat utang atau sukuk. ${ }^{7}$

Securities crowdfunding berbeda dengan fintech peer to peer landing disini Securities crowdfunding, investor bertindak sebagai pemodal yang keuntungannya berasal dari dividen (jika berjenis saham) kupon atau nisbah (jika berjenis obligasi / sukuk), penjualan efek (pasar sekunder) dan keuntungan lainnya. Sementara pada fintech peer to peer landing biasanya berasal dari bunga yang bersifat tetap. Dalam Securities crowdfunding ini ada tiga pihak yang terlibat yaitu (i) penyelenggara yang memiliki izin dari otoritas jasa keuangan, (ii) penerbit selaku pemilik usaha - dan (iii) pemodal.

Pelaku usaha mikro selaku pemilik usaha dapat memanfaatkan skema Securities crowdfunding dalam memulai usaha atau juga dalam pengembangan usaha dengan begitu permasalahan utama keterbatasan modal sebagai landasan usaha mikro sulit berkembang kini dapat teratasi dengan adanya Securities crowdfunding sebagai alternatif pembiayaan bagi pelaku usaha mikro. Tentu pelaku usaha mikro juga harus dapat lebih kreatif dan inovatif mengingat sektor pembiayaan ini sangat memudahkan pelaku usaha mikro yang sangat sulit mengakses pasar modal lantaran badan usahanya yang belum memenuhi kriteria pendanaan.

Seiring dengan perkembangan teknologi sebagai sarana bagi masyarakat dan pelaku usaha khususnya dalam kegiatan ekonomi yang dilakukan sehari-hari yang memberikan dampak yang sangat signifikan terhadap ilmu pengetahuan dan teknologi dengan tujuan teknologi sebagai sarana pembangunan dan didampingi dengan hukum sebagai regulasi yang memberikan kepastian hukum bagi pelaku usaha dan masyarakat sebagai konsumen. Pembiayaan securities crowdfunding merupakan salah satu alternatif pendanaan dan sebagai sarana hukum pembangunan berbasis teknologi melalui layanan urun dana.

Diantara jenis crowdfunding, securities crowdfunding memiliki kesamaan dengan IPO secara prinsip melalui penawaran saham kepada umum. Namun yang menjadi pembeda adalah securities crowdfunding ditujukan kepada pelaku usaha mikro dan perusahaan kecil lainnya dan sebagai alternatif dari penghimpunan dana dengan imbal saham. ${ }^{8}$

\section{Rumusan Masalah}

Pembahasan diatas terkait dengan pokok permasalahan dalam kajian ini dikembangkan dengan dilandasi beberapa pertanyaan pokok sebagai berikut :

1. Apakah kebijakan securities crowdfunding dapat memberikan kepastian hukum dalam peningkatan kapasitas usaha mikro?

2. Bagaimana pengembangan usaha mikro melalui securities crowdfunding dalam perspektif hukum pembangunan?

\section{Metode penelitian}

Metode Penelitian yang digunakan dalam penelitian ini adalah menggunakan metode kepustakaan dengan menggunakan jenis data berupa data sekunder. ${ }^{9}$ Data sekunder ini terdiri

\footnotetext{
${ }^{7}$ Lihat Peraturan Otoritas Jasa Keuangan Nomor 57/2020 tentang Penawaran Efek Melalui Layanan Urun Dana berbasis teknologi.

${ }^{8}$ Cindy Indudewi Hutomo, Layanan Urun Dana Melalui Penawaran Saham Berbasis Teknologi Informasi, Jurnal Perspektif : Kajian Masalah Hukum dan Pembangunan, Vol 24 No 2 Tahun 2019, Hlm 66

${ }^{9}$ Soerjono Soekanto, Pengantar Penelitian Hukum, Cetakan 8, UI-Press, Jakarta, 2018, Hlm 10-13
} 
Vol. 4 No. 1 Januari 2022

dari bahan hukum primer, bahan hukum sekunder dan bahan hukum tersier. ${ }^{10}$ Metode pengolahan dan analisisis data yang digunakan penulis adalah dengan menggunakan metode kualitatif, walaupun dalam paparannya juga digunakan data kuantitatif untuk mendukung analisis, khususnya data mengenai peraturan daerah yang telah ada menyangkut bidang perizinan. Dengan metode kualitatif maka kemudian diutamakan kualitas dan kevalidan data dari data sekunder yang akan digunakan dan bukan dari jumlah atau kuantitasnya. Metode kualitatif ini akan menghasilkan data deskriptif analitis bahwa apa yang dinyatakan oleh sasaran penelitian yang bersangkutan akan dinyatakan secara tertulis maupun secara lisan dan perilaku nyata. $^{11}$

\section{B. PEMBAHASAN}

\section{Kebijakan Securities Crowdfunding Dapat Memberikan Kepastian Hukum Dalam Peningkatan Kapasitas Usaha Mikro}

Usaha mikro di Indonesia merupakan pilar pendorong ekonomi yang memberikan potensi yang sangat baik untuk dikembangkan. ${ }^{12}$ Namun seiring perkembangan dari usaha mikro memiliki beberapa permasalahan dimana masalah utama masih seputar permodalan atau pembiayaan yang masih belum menyentuh usaha mikro dan minimnya lembaga keuangan yang melirik usaha mikro untuk dapat memberikan pembiayaan. Sulitnya usaha mikro dalam mengakses perbankan karena karakter usaha dari usaha mikro adalah usaha informal yang belum memenuhi kriteria dari bank dalam pemberian kredit. ${ }^{13}$

Era digital berbasis teknologi beberapa tahun memperkenalkan sistem pembiayaan berbasis digital seperti fintech peer to peer landing dan crowdfunding. Fintech dikembangkan untuk dapat memudahkan pelaku usaha dalam mengakses pembiayaan. ${ }^{14}$ Namun fintech peer to peer landing masih memberikan dampak yang berat bagi usaha mikro secara langsung karena mengingat beban bunga yang diberikan terkadang lebih besar dari lembaga perbankan atau lembaga pembiayaan lainnnya.

Berbeda dengan crowdfunding yang merupakan sistem dari penghimpunan dana dari masyarakat berbasis digital. Penghimpunan dana relatif sangat kecil namun dengan banyaknya jumlah pemberi dana maka dana yang dikumpulkan juga menjadi besar jumlahnya. Crowdfunding di Indonesia banyak digunakan untuk beberapa kegiatan sosial diantaranya aplikasi yang sering digunakan adalah kitabisa.com yang bertujuan untuk membantu masyarakat yang bertujuan mulai dari dana pendidikan, bantuan bencana alam, bantuan modal usaha dan lain-lain.

Pemerintah sebagai fasilitator memberikan kebijakan yang diamanatkan dalam Pasal 22 Undang-Undang Nomor 20 Tahun 2008 tentang UMKM dijelaskan bahwa dalam rangka meningkatkan aspek pembiayaan bagi usaha mikro seperti sumber pembiayaan jasa perbankan,

\footnotetext{
${ }^{10}$ Mukti Fajar dan Yulianto Achmad, Dualisme Penelitian Hukum Normatif dan Empiris, Pustaka Pelajar, Yogyakarta, 2015, Hlm 156

11 Ibid

12 Irawati, Tinjauan yuridis pemanfaatan equity crowdfunding bagi pengembangan usaha kecil dan menengah di Indonesia, Jurnal Diponegoro Law Review, Vol 4 No 2 Tahun 2019 Hlm 2

${ }^{13}$ Cut Misni Mulasiwi dan Karina Odia Julialeva, Optimalisasi Financial Technologi Terhadap Peningkatan Literasi Dan Inklusi Keuangan Usaha Menengah Purwokerto, Jurnal Personalia, Financial, Operasional, Marketing dan Informasi, Vol 27 No 1 Tahun 2020, Hlm 14

${ }^{14}$ Evy Nur Sugiarti, Nur Diana dan M Colid, Peran Fintech Dalam Meningkatkan Literasi Keuangan Pada Usaha Mikro Kecil dan Menengah di Malang, Jurnal Akuntansi, Vol 8 No 4 Tahun 2019. Hlm 91
} 
Vol. 4 No. 1 Januari 2022

sumber pembiayaan modal ventura, sumber pembiayaan anjak piutang, Koperasi serta pembiayaan lain yang diatur oleh Undang-Undang. ${ }^{15}$ Selain dari Undang-Undang Nomor 22 Tahun 2008 tentang UMKM lebih lanjut juga dijelaskan kedalam Peraturan Pemerintah Nomor 17 Tahun 2013 tentang pelaksanaan UU UMKM salah satunya pada pasal 8 ayat (4) dengan mencari sumber pendanaan yang lebih luas. ${ }^{16}$

Merujuk pada pembiayaan lain dapat dijumpai pada pembiayaan berbasis keuangan mikro atau yang dikenal dengan Lembaga Keuangan Mikro dan Crowdfunding namun sampai saat ini Undang-Undang yang secara khusus mengatur mengenai crowdfunding belum diatur secara rinci dan hanya ada beberapa peraturan terkait seperti Peraturan Otoritas Jasa Keuangan saja. ${ }^{17}$ Selain peraturan terkait yang belum rinci hal yang paling mendasar adalah legalitas usaha khususnya bagi pengelola crowdfunding dimana masih banyaknya perusahaan yang belum memenuhi kriteria dan beberapa cenderung belum terdaftar di Otoritas Jasa Keuangan.

Konsep crowdfunding ini sendiri menurut morduch yang merupakan konsep micro finance. ${ }^{18}$ Namun karakter crowdfunding ini sendiri cenderung unik dan sangat berbeda dengan konsep sebelumnya. Jadi konsep crowdfunding sendiri bukanlah hal baru namun yang menjadi sarana pembahruan adalah hadirnya teknologi didalamnya untuk bertransformasi secara digital dimana salah satu sektor yang dapat memanfaatkan pendanaan ini adalah usaha mikro. ${ }^{19}$

Selain penghimpunan dana berbasis digital seperti website dan aplikasi alternatif lain sebagai pengembangan crowdfunding adalah equity crowdfunding dimana konsep equity crowdfunding ini digagas pada Tahun 2018 lalu melalui Peraturan Otoritas Jasa Keuangan Nomor 37 Tahun 2018 tentang Layanan Urun Dana Melalui Penawaran Saham Berbasis Teknologi Informasi. Pada Tahun 2019 beberapa platform penyedia crowd funding terdaftar Otoritas Jasa Keuangan Per 2019 seperti Santara, Bizhare, dan Crowddana. Regulasi POJK No 37 Tahun 2018 ini memberikan kepastian hukum untuk menjaga kebutuhan para pihak mulai dari penyelenggara, dan pemodal. Walaupun memang masih banyak penyesuaian yang dilakukan dilapangan dalam rangka implementasi POJK serta menyesuaikan kebutuhan bagi para pelaku usaha guna memberikan kepastian hukum bagi pihak yang terlibat terutama bagi para pelaku usaha mikro.

Tumbuhnya equity crowdfunding ditengah animo pelaku usaha dalam rangka pemenuhan kebutuhan pembiayaan membuat Otoritas Jasa Keuangan mengeluarkan aturan kebijakan baru pengganti POJK No 37 Tahun 2018 dengan POJK 57 Tahun 2020 terbitnya kebijakan tersebut adalah sebagai langkah untuk memberikan kepastian hukum serta perlindungan bagi pemodal. Selain itu penyelenggara dituntut untuk dapat meningkatkan tata kelola perusahaan yang baik. Aturan OJK ini ditujukan bagi pelaku usaha mikro untuk mendapatkan sumber pendanaan alternatif selain dari lembaga perbankan.

Selain dari efek bersifat ekuitas dalam POJK 57 Tahun 2020 ini juga mencakup efek bersifat utang atau sukuk dengan begitu diharapkan pelaku usaha mikro dapat meningkatkan

${ }^{15}$ Lihat Undang-Undang Nomor 20 Tahun 2008 tentang Usaha mikro, Kecil dan Menengah.

${ }^{16}$ Lukmanul Hakim, Etty Mulyati, Djuhaendah Hasan dan Tarsisius Murwadji, Legal Aspects of Micro Business Development Institutions in State Purpose of Welfare, Fiat Justisia : Jurnal Ilmu Hukum, Vol 14 No 3 Tahun 2020, Hlm 249

${ }^{17}$ Alvia Indriasari, Nyulistiowati Suryanti, dan Anita Afriana, Pembiayaan Usaha Mikro, Kecil dan Menengah, melalui Situs Crowdfunding "Patungan.Net" Dikaitkan dengan Undang-Undang Nomor 20 Tahun 2008 tentang UMKM, Acta Diurnal : Jurnal Hukum Kenotariatan dan Ke PPATan, Vol 1 No 1 Tahun Desember 2017, HIm 90

${ }^{18} \mathrm{~J}$ Morduch, The Microfinance Promise, Journal of Economic Literature, XXXVII, (1999) 15691614. Retrieved from https://wagner.nyu.edu/files/faculty/publications/1999- 12 Microfinance_Promise.pdf.

${ }^{19}$ Arief Yuswanto Nugroho dan Fatichatur Rachmaniyah, Fenomena Perkembangan Crowdfunding di Indonesia, Jurnal Ekonika, Vol 4 No 1 Tahun 2019, Hlm 37 
Vol. 4 No. 1 Januari 2022

kapasitasnya untuk mengembangkan usaha seperti menambah stok barang atau dapat membuka tempat usaha baru atau cabang usahanya tanpa perlu lagi kesusuahan mencari pembiayaaan. Dengan jangka waktu 1 Tahun atau 1 kali atau beberapa penawaran dimana efek yang ditawarkan bersifat utang dengan nilai maksimal 10 Miliar dimana masa penawaran berlangsung 45 Hari. Selanjutnya penawaran batal demi hukum apabila minimum dana tidak terpenuhi atau tidak sesuai dengan aturan perundang-undangan.

Menurut data Otoritas Jasa Keuangan saat ini ada 23 calon penyelenggara dari securities crowdfunding yang akan membantu pelaku usaha mikro mendapatkan alternatif pembiayaan. Adapun penyelenggara telah memiliki izin serta terdaftar pada Otoritas Jasa Keuangan dan pendampingan Asosiasi Layanan Urun Dana Indonesia (ALUDI) yang akan meberikan pembinaan serta membina apabila terjadi pelanggaran, selain itu kepentingan investor juga akan lebih terlindungi.

Securities Crowdfunding sendiri memberikan ruang bagi usaha mikro yang belum bankable untuk dapat ikut serta mendapatkan pendanaan. Selain itu juga securities crowdfunding memiliki keunggulan lainnya seperti penggalangan dana tidak memerlukan biaya besar, tidak membutuhkan jaminan secara khusus sehingga sangat sesuai sekali dengan usaha mikro dan perusahaan kecil. ${ }^{20}$

Dengan adanya kebijakan terbaru yang dikeluarkan oleh OJK dalam rangka mengubah aturan POJK sebelumnya dari POJK No 37 Tahun 2018 ke POJK No 57 Tahun 2020 diharapkan mampu menjadi regulasi yang memberikan kepastian hukum kepada para pihak securities crowdfunding terutama pelaku usaha mikro yang sangat membutuhkan pembiayaan sehingga securities crowdfunding dapat menjadi salah satu alternatif pembiayaan ditengah keterbatasan pelaku usaha.

\section{Pengembangan Usaha Mikro Melalui Securities Crowdfunding Dalam Perspektif Hukum Pembangunan}

Hukum adalah suatu bagian yang merupakan hasil dari cipta karya dan karsa manusia yang diwujudkan kedalam sebuah produk hukum untuk dapat menegakkan keadilan dan mewujudkan kesejahteraan bagi seluruh masyarakat. Oleh karenanya hukum pada hakekatnya untuk melindungi kepentingan manusia.

Mengenai tujuan hukum seperti yang kita ketahui adalah untuk menciptakan ketertiban, keadilan, kepastian dan kesejahteraan. Menurut Mochtar Kusumaatmadja mengatakan bahwa dengan terwujudnya ketertiban pada masyarakat diharapkan kepentingan masyarakat juga akan dapat dilindungi. ${ }^{21}$

Lebih lanjut hukum memiliki fungsi terutama dalam pembangunan nasional yang digambarkan dengan kata hukum adalah sebagai sarana pembaharuan atau sebagai sarana daripada pembangunan itu sendiri dengan tujuan menjamin kepastian hukum serta keadilan pada masyarakat. ${ }^{22}$ Hukum sebagai sarana pembaharuan merupakan grand design yang bertumpu pada perubahan yang melibatkan masyarakat dalam menciptakan kesejahteraan.

Bicara mengenai kesejahteraan terutama bagi masyarakat dan para pelaku usaha mikro juga harus dapat berperan aktif khususnya dalam proses perumusan dalam sebuah kebijakan. Mengingat di era modern saat ini masyarakat maupun pelaku usaha mikro telah merubah

${ }^{20}$ Cindy Indudewi, Op. Cit, Hlm 73

${ }^{21}$ Mochtar Kusumaatmadja, Mochtar Kusumaatmadja dan Teori Hukum Pembangunan, Epistema Institute dan Huma, Jakarta, 2012, Hlm 14

${ }^{22}$ Mochtar Kusumaatmadja, Konsep-Konsep Hukum Pembangunan, Cetakan I, Alumni, Bandung, 2002, Hlm 88 
Vol. 4 No. 1 Januari 2022

kebiasaan yang semula konvensional atau tradisional kini beralih kepada digitalisasi teknologi berbasis elektronik.

Teori Hukum Pembangunan harus mampu menjawab sejumlah kasus yang terjadi seperti halnya perlindungan terhadap pelaku usaha mikro di era digital saat ini. Mengingat usaha mikro merupakan bagian dari pembangunan ekonomi nasional, lokal maupun regional sebagai langkah konkrit sesuai amanat Pasal 33 UUD 45 di era digital saat ini.

Perkembangan teknologi digital memberikan banyak perubahaan serta pembaharuan dalam kebiasaan masyarakat terutama kemajuan teknologi finansial berbasis digital sebagai langkah yang lebih efektif dan efisien. Seiring perkembangan teknologi digital sebagai sarana mencapai tujuan sangat berkaitan erat dengan hukum yang mengiringi perkembangan ilmu dan teknologi.

Perkembangan teknologi membawa pembaharuan dalam sarana prasarana pembangunan infrastruktur terutama dalam aspek finansial dan aspek pembiayaan bagi para pelaku usaha mikro yang berada pada situasi kesulitan pendanaan. Salah satu permasalahan para pelaku usaha mikro yang seperti kita ketahui yang sangat krusial adalah masal modal atau pembiayaan. Untuk dapat mengembangkan usahanya pelaku usaha mikro membutuhkan pembiayaan, namun dalam hal ini usaha mikro masih memiliki keterbatasan untuk dapat mengakses pembiayaan dari sektor lembaga perbankan dan pembiayaan lainnya.

Seiring perkembangan zaman serta teknologi berbasis elektronik sebagai sarana pembangunan teknologi sebagai metode dalam pengembangan usaha mikro khususnya dalam aspek pembiayaan dimana sarana pembaharuan pembiayaan usaha mikro dapat memanfaatkan securities crowdfunding sebagai alternatif pembiayaan bagi pelaku usaha mikro yang masih mengalami kesulitan modal dan masih dikatakan belum bankable namun sudah feasible.

Securities crowdfunding merupakan sarana pembiayaan pengganti dari equity crowdfunding. Peraturan mengenai Securities crowdfunding diperluas kembali dengan mencakup efek bersifat utang atau sukuk dimana peraturan ini tercantum pada POJK No 57 Tahun 2020 yang diterbitkan pada bulan desember 2020 POJK ini hadir sebagai alternatif bagi pelaku usaha mikro pemula dalam mencari pembiayaan.

Teknologi memiliki fungsi sebagai sebagai metode berfikir serta sarana untuk mencapai suatu tujuan dapat dioptimalisasi sehingga diharapkan dapat lebih efektif serta efisien dalam penerapan di kehidupan masyarakat sebagai konsumen dan usaha mikro sebagai pelaku usaha. Melalui Otoritas Jasa Keuangan mendorong pelaku usaha mikro yang selama ini masih mengandalkan permodalan dari lembaga perbankan untuk mulai mengakses dana publik sebagai sumber permodalan, salah satunya melalui securities crowdfunding.

Securities crowdfunding sangat berbeda dengan fintech peer to peer landing dan pengaturannya juga sangat berbeda. Selain itu skema atau cara kerja dari Securities crowdfunding melibatkan pihak seperti penerbit yang akan mengeluarkan efek (saham atau EBUS $)^{23}$ akan berhubungan dengan penyelenggara, selanjutnya penyelenggara akan melakukan due diligence ${ }^{24}$ terlebih dahulu terhadap penerbit, kemudian melakukan perjanjian, kemudian penyelenggara akan membantu menawarkan saham atau efek penerbit tadi melalui situs yang sudah berizin, agar dapat dilihat oleh calon pembeli.

Securities crowdfunding sangat berkaitan dengan sarana pembangunan teknologi dan sarana pembaharuan dalam pembiayaan bagi pelaku usaha mikro pada khususnya. Pengaturan Securities crowdfunding yang telah diterbitkan oleh Otoritas Jasa Keuangan adalah sebagai

\footnotetext{
${ }^{23}$ EBUS adalah perantara pedagang efek untuk efek bersifat utang dengan sukuk

${ }^{24}$ Due Diligence adalah uji tuntas dimana istilah yang digunakan untuk penyelidikan penilaian kinerja perusahaan atau seseorang dari suatu kegiatan guna memenuhi standar baku yang tepat. Istilah uji tuntas dapat digunakan dalam menunjukan suatu kegiatan penilaian terhadap ketaatan hukum.
} 
Vol. 4 No. 1 Januari 2022

bukti regulasi untuk dapat memberikan kepastian hukum tidak hanya bagi investor namun juga bagi para pelaku usaha mikro pada khususnya.

Teori Hukum Pembangunan yang dikemukakan oleh mochtar membuka ruang komunikasi dan mendorong mampu untuk melihat fakta sosial yang terjadi pada masyarakat saat ini terutama di era perkembangan teknologi untuk membangun aspirasi masyarakat terutama pelaku usaha. Pembangunan teknologi yang tercermin sebagai sebuah sarana perubahan sosial saat ini dan pembaharuan masyarakat. Rekonstruksi pembangunan hukum dalam digitalisasi terutama dalam aspek pembiayaan seperti Securities crowdfunding dalam konteks pembentukan hukum dibidang usaha mikro yang senantiasa diarahkan kepada daya dukung daripada masyarakat (legal culture) untuk menciptakan kesejahteraan sosial bagi seluruh masyarakat dan pelaku usaha.

Berdasarkan uraian diatas penulis menyimpulkan bahwa dengan adanya Securities crowdfunding sebagai salah satu alternatif pembiayaan bagi pelaku usaha mikro diharapkan mampu mengembangkan usaha mikro dutengah kesulitan akses pembiayaan dan mampu untuk meningkatkan kapasitas usaha mikro yang semula berkarakteristik infornal diharapkan akan menjadi usaha formal sehingga usaha mikro tidak lagi dikatakan belum bankable.

\section{Penutup}

\section{Kesimpulan} berikut :

Berdasarkan uraian pembahasan diatas penulis dapat memberikan kesimpulan sebagai

1. Kebijakan securities crowdfunding dapat memberikan kepastian hukum dalam peningkatan kapasitas usaha mikro karena dengan adanya pengaturan terbaru pada layanan urun dana yang semula adalah equity crowdfunding menjadi securities crowdfunding memberikan dampak yang sangat positif khususnya dalam hal memberikan kepastian hukum bagi pelaku usaha mikro serta memberikan perlindungan hukum terhadap investor juga tentunya. Mengingat securities crowdfunding sangat berbeda dengan pengaturan pada financial technology dan tentunya kebijakan securities crowdfunding ini memberikan keunggulan dan tidak menggunakan biaya yang relatif besar.

2. Pengembangan usaha mikro melalui securities crowdfunding dalam perspektif hukum pembangunan ini dimaksudkan untuk Rekonstruksi pembangunan hukum dalam digitalisasi terutama dalam aspek pembiayaan seperti Securities crowdfunding dalam konteks pembentukan hukum dibidang usaha mikro yang senantiasa diarahkan kepada daya dukung daripada masyarakat (legal culture) untuk menciptakan kesejahteraan sosial bagi seluruh masyarakat dan pelaku usaha.

\section{Saran}

Adapun saran yang penulis berikan adalah sebagai berikut :

Perlunya Instrumen Hukum yang lebih up to date terutama Undang-Undang yang secara khusus mengatur mengenai bidang technology financial. Mengingat pesatnya perkembangan teknologi pada masyarakat di era modern saat ini sehingga perlu adanya secara khusus mengenai rancangan peraturan mengenai digitalisasi layanan financial maupun inklusi keuangan khususnya kebijakan terkait pelaku usaha mikro. 
Vol. 4 No. 1 Januari 2022

\section{Daftar Pustaka}

\section{Buku :}

Mukti Fajar dan Yulianto Achmad, Dualisme Penelitian Hukum Normatif dan Empiris, Pustaka Pelajar, Yogyakarta, 2015,

Mochtar Kusumaatmadja, Mochtar Kusumaatmadja dan Teori Hukum Pembangunan, Epistema Institute dan Huma, Jakarta, 2012.

Mochtar Kusumaatmadja, Konsep-Konsep Hukum Pembangunan, Cetakan I, Alumni, Bandung, 2002.

Soerjono Soekanto, Pengantar Penelitian Hukum, Cetakan 8, UI-Press, Jakarta, 2018.

\section{Jurnal :}

Alvia Indriasari, Nyulistiowati Suryanti, dan Anita Afriana, Pembiayaan Usaha Mikro, Kecil dan Menengah, melalui Situs Crowdfunding "Patungan.Net" Dikaitkan dengan Undang-Undang Nomor 20 Tahun 2008 tentang UMKM, Acta Diurnal : Jurnal Hukum Kenotariatan dan Ke PPATan, Vol 1 No 1 Tahun Desember 2017.

Arief Yuswanto Nugroho dan Fatichatur Rachmaniyah, Fenomena Perkembangan Crowdfunding di Indonesia, Jurnal Ekonika, Vol 4 No 1 Tahun 2019.

Ayu Putu Yulia Kusuma Wardani Dan Nyoman Ari Surya Darmawan, Peran financial technology pada UMKM : Peningkatan literasi keuangan berbasis payment gateaway, Jurnal Ilmiah Akuntansi dan Humanika, Vol 10 No 2, Mei- Agustus 2020.

Cindy Indudewi Hutomo, Layanan Urun Dana Melalui Penawaran Saham Berbasis Teknologi Informasi, Jurnal Perspektif : Kajian Masalah Hukum dan Pembangunan, Vol 24 No 2 Tahun 2019.

Cut Misni Mulasiwi dan Karina Odia Julialeva, Optimalisasi Financial Technologi Terhadap Peningkatan Literasi Dan Inklusi Keuangan Usaha Menengah Purwokerto, Jurnal Personalia, Financial, Operasional, Marketing dan Informasi, Vol 27 No 1 Tahun 2020.

Eka Travilta Oktaria dan Desi Derina Yusda, Efektivitas Penerapan Tanggung Jawab Sosial Perusahaan Terhadap Pengembangan Usaha mikro, Jurnal Ekombis, Vol 5 No 1 Tahun 2020.

Eka Travilta Oktaria, Pengembangan UMKM Dalam Pembiayaan Berbasis Koperasi Dalam Rangka Peningkatan Ekonomi di Indonesia, Jurnal Ekombis, Vol 3 No 1 Tahun 2018.

Evy Nur Sugiarti, Nur Diana dan M Colid, Peran Fintech Dalam Meningkatkan Literasi Keuangan Pada Usaha Mikro Kecil dan Menengah di Malang, Jurnal Akuntansi, Vol 8 No 4 Tahun 2019.

Hanik Fitriani, Kontribusi Fintech dalam Meningkatkan Keuangan Inklusif pada Pertanian. ElBarka : Jurnal Of Islamic Economics And Business, Vol 1 No 1 Tahun 2018.

Irawati, Tinjauan yuridis pemanfaatan equity crowdfunding bagi pengembangan usaha kecil dan menengah di Indonesia, Jurnal Diponegoro Law Review, Vol 4 No 2 Tahun 2019.

J Morduch, The Microfinance Promise, Journal of Economic Literature, XXXVII, (1999) 15691614. Retrieved from https://wagner.nyu.edu/files/faculty/publications/1999- 12 Microfinance_Promise.pdf. 


\section{Res Nullius}

Vol. 4 No. 1 Januari 2022

Lukmanul Hakim, Etty Mulyati, Djuhaendah Hasan dan Tarsisius Murwadji, Legal Aspects of Micro Business Development Institutions in State Purpose of Welfare, Fiat Justisia : Jurnal Ilmu Hukum, Vol 14 No 3 Tahun 2020.

Sifwatir Rif'ah, Fenomena Cashless Society di Era Milenial Dalam Perspektif Islam, AlMusthofa: Journal of Sharia Economics, Vol 2, No 1 Tahun 2019.

\section{Peraturan dan Perundang-Undangan :}

(Amandemen Keempat) Undang-Undang Dasar 1945.

Undang-Undang Nomor 20 Tahun 2008 tentang Usaha mikro, Kecil dan Menengah.

Peraturan Otoritas Jasa Keuangan Nomor 37/2018 tentang Layanan Urun Dana Melalui Penawaran Saham Berbasis Teknologi Informasi.

Peraturan Otoritas Jasa Keuangan Nomor 57/2020 tentang Penawaran Efek Melalui Layanan Urun Dana berbasis teknologi.

\section{Sumber Lain :}

https://teknologi.bisnis.com/read/20201110/ diakses pada tanggal 11 Februari 2021. 